\title{
CONCEPT «DESTINY»: FEATURES OF REPRESENTATION IN POLISH LINGVOCULTURE
}

\section{Lutsenko Valentyna}

Candidate in Pedagogy, Associate professor

ORCID ID 0000-0002-4583-7985

National Technical University «Dnipro Polytechnic»

Dmytro Avornitsky b., 19, 49000, Dnipro, Ukraine

astra4965@gmail.com

\section{Lutsenko Olga}

ORCID ID 0000-0003-4080-9392

Head of the educational and methodical office

State Enterprise of Ukraine «International Children's Center «Artek»

Pushcha-Vodytsya 14th line, 01000, «Artek», Kyiv, Ukraine

olya.lucenko@gmail.com

Concept «los» («destiny») as a key in the Polish culture has many lexical representation. «Destiny» in Polish is the life, the existence of someone or something; future, sequence of events; the supreme regulatory beginning. Destiny is thought of as contradictory, ambivalent beginning. It is able to help or hinder. Carriers of the Polish language are ambivalent in their relation to the destiny. Presence of the destiny may either be approved or denied. Poles have different views on the nature of destiny. On the one hand, destiny is presented as unchangeable and predefined from above. On the other, there is a view that it is created during the life (existence), and, for example, a person can have a significant influence on it. Metaphorically in Polish destiny is represented by the signs of person, connecting or disconnecting, gracious or formidable beginning.

Introduction. The relevance of the study is due to the increased attention of scientists to culturally significant concepts as components of the conceptual picture of the world. Despite the fact that the concept of destiny has been reflected in detail on the material of different languages of the world, in linguistics there are many problems regarding the linguistic interpretation of this culturological phenomenon, including its multilevel structure.

The aim of the research is to clarify the linguistic features of the concept of destiny in Polish linguistic culture.

Materials and methods of research (detailed description of what material and what methods were used in the research, 3000 - 4000 characters with spaces).

The work is performed on the basis of substantiation of theoretical and methodological bases of studying the specifics of objectification of the concept; analysis of the linguistic features of the concept of «los», which is represented by numerous units (tokens, including metaphors, phraseology). The concept of «los» is multilevel in its structure: on the one hand, fate - is a series of events in the life (existence) of someone or something, the future, on the other hand, fate is a higher principle that determines the course of events and features of the life of a subject.

Discussion. Historiography of the problem is to study different types of dictionaries.

The results of the research are the main text of the article (the course of the research is described, its main results are stated, indicating the new one proposed by the author to solve this problem).

Based on the study of different types of dictionaries, the structure of the concept of «los» is determined, the emphasis is on the interpretation of the above concept in stable phrases. The study of lexical-semantic fields and related intrafield and interfield relations has been productive in this regard. The level structure is also determined and the figurative

(C) Lutsenko V., Lutsenko O., 2020 
component of the culturological concept «los» is revealed.

Conclusions and perspectives. Fate is one of the most profound concepts of the Polish cultural area. The semantics of this concept gives us an understanding of the allencompassing human life and the action of various factors on it. Analyzing numerous tokens (15 synonyms, 40 phraseological units with components "los / przeznaczenie / fortuna»), we have identified a number of microconcepts that are the semantic embodiment of the central concept of Fate.

Key words: concept, lingvoculture, Polish language, lexical representation, conceptual metaphor.

\section{POJECIE «LOS»: CECHY REPREZENTACYJNE W JEZYKOZNAWSTWIE POLSKIM}

\section{Lucenko Valentyna}

Kandydat nauk pedagogicznych, docent

ORCID ID 0000-0002-4583-7985

Narodowy Uniwersytet Techniczny «Politechnika Dnieprowska»

prospekt Dmytra Jawornyckiego, 19, 49000, Dniepr, Ukraina

astra4965@gmail.com

\section{Lucenko Olga}

ORCID ID 0000-0003-4080-9392

Kierownik gabinetu dydaktyczno-metodycznego

Przedsiębiorstwo Państwowe Ukrainy «Międzynarodowe Centrum Dziecka «Artek» Puszcza-Vodyca 14 linia, 01000, «Artek», Kijów, Ukraina olya.lucenko@gmail.com

Aktualność badania jest określona wzmocniona uwaga naukowców do kulturalnie znaczacych konceptów jak składowych konceptualnego obrazu świata. Mimo to, że pojęcie losu otrzymało dokładne odzwierciedlenie na materiale różnych języków świata, $w$ językoznawstwie zostaja sporo problemów stosujacych mownej interpretacji tego kulturologicznego zjawiska, w tym i z wielostopniowej jego struktury.

Cel badania polega $w$ wyjaśnieniu mownych właściwości konceptu los $w$ polskiej lingwokulturze.

Materialy i metody badania (dokładny opis tego, na którym materiale $i$ którymi metodami spetniało się badanie, 3000 - 4000 znaków z lukami).

Praca jest dokonana na podstawie uzasadnienia teoretyko-metodologicznych zasad nauczania specyfiki uprzedmiotowienia konceptu; analizie mownych właściwości konceptu «los», który reprezentuje licznymi jednostkami (leksemami, w szczególności metaforami, frazeologizmami). Koncept «los» jest wielostopniowy za swoja struktura: z jednej strony, losto szereg wydarzeń w życiu (istnieniu) kogokolwiek albo czegokolwiek, przyszłość, z drugiej strony, los przedstawia niektóry wyższy początek, co wyznacza przebieg wydarzeń $i$ właściwości życia pewnego subiektu.

Dyskusja. Historiografia poruszonego problemu polega $w$ nauczaniu różnych rodzajów słowników.

Wyniki badania - glówny tekst artykułu (opisuje się przebieg badania, wyktadaja się główne jego wyniki z zaznaczaniem tego nowego, co proponuje autor dla rozwiąania zaznaczonego problemu).

Na podstawie nauczania różnych rodzajów słowników określono strukturę konceptu

«los», akcent zrobiono na interpretacji nazwanego wyżej konceptu $w$ odpornych połaczeniach słów. Produkcyjnym $w$ tym planie stało się badanie leksyko-semantycznych pól $i$ zwiąanych $z$ nimi wewnątrzpolnych $i$ międzypolnych stosunków. Określono również poziomowa strukturę i ujawniono obrazowa składowa kulturologię konceptu «los».

Wnioski i perspektywy. Los - jeden z najbardziej głębokich konceptów polskiego kulturalnego areału. Semantyka tego konceptu daje nam rozumienie wszechstronnego życia 
czlowieka i działania na niego różnych czynników. Analizując liczne leksemy (15 synonimów, 40 frazeologicznych jednostek ze składnikami «los / przeznaczenie / fortuna»), wyróżniliśmy szereg mikrokonceptów, które sa pojęciowym wcieleniem centralnego konceptu Los.

Streszczenie. W artykule pojęcie «los» jest jednym z kluczowych w polskiej kulturze. $W$ języku polskim pojęcie to jest reprezentowane przez liczne jednostki (leksemy, w tym metafory, frazeologizmy). Koncepcja «los» jest wielopoziomowa w swojej strukturze: z jednej strony los jest seriq wydarzeń w życiu (istnieniu) kogoś lub czegoś, przyszlość, z drugiej strony los jest rodzajem wyższego porzadku, który określa przebieg wydarzeń $i$ cechy życia pewnego podmiotu. W polskim językoznawstwie los jest myślany i przedstawiany poprzez szereg przeciwstawnych cech, charakterystyk, ocen.

Slowa kluczowe: koncepcja, językoznawstwo, język polski, reprezentacja leksykalna, metafora pojęciowa.

\section{Wprowadzenie}

Świat, dany człowiekowi w różnych formach jego odczuć (wzrokowych, słuchowych, dotykowych itp.), przechodzi skomplikowaną drogę transformacji od tego prostego odczucia, przechodzącego w pewną reprezentację, do tworzenia treści konceptualnych, to znyczy pewnego pojęcia, koncepcji - w kategoriach współczesnej lingwistyki kognitywnej. Materiały i metody badania. Koncept - jednostka mentalna, ukazująca właściwości podmiotowe danego obiektu. Część koncepcji, jako formacji strukturalnej, jest zobiektywizowana w formie znaku językowego. Według Witalija Kononenka, «Koncepcje mają różne formy uprzedmiotowienia, wśród których język odgrywa pierwszorzędną rolę» (Kononenko, 2004:89). Rzeczywiście, przedmioty poznane przez człowieka, tradycyjnie dzielą się na konkretne (dom, ptak, stół itp.) i abstrakcyjne (życie, przeznaczenie, szczęście itp.). Dyskusja. Te pierwsze można zobaczyć, dotknąć czy usłyszeć, a w tym przypadku takiego doświadczenia percepcyjnego wystarczy aby stworzyć podstawową wiedzę o tym obiekcie. Postrzeganie, a co najważniejsze zrozumienie postrzeganego ze sfery abstrakcyjnej, jego przejście na drodze konceptualizacji nie jest możliwe bez takiego systemu symbolicznego, jak język. Z jednej strony, dokładnie znaki językowe, poprzez bezpośrednią nominację identyfikują pewien abstrakcyjny obiekt, udostępniają go do «postrzegania», z drugiej - nasza świadomość, w tym język, działa na to, aby nawiązać połączenia tego obiektu $\mathrm{z}$ innymi obiektami, poszerzyć istniejącą reprezentację o nim.

Koncepcja jest obiektywizowana poprzez słowa, wolne kombinacje słów, frazeologizmy, zdania, teksty. Podstawą struktury koncepcji są cechy pojęciowe, «wyróżniające się poprzez analizę semantycznej struktury słów reprezentujących koncepcję» (Kononenko, 2004:94). W języku polskim typowym reprezentantem pojęcia «los» jest rzeczownik o tej samej nazwie. We współczesnym języku polskim rzeczownik los ma trzy znaczenia (2):

1) «dola, koleje życia lub bieg zdarzeń»;

2) «przeznaczenie, fatum»;

3) «kartka z numerem, rzadziej kostka, gałka, których wyciągnięcierozstrzyga o wygranej lub przegranej».

Pod względem pochodzenia polskie «los» jest zapożyczeniem niemieckim, które już w XIV wieku w języku polskim zastąpiło właściwie słowiańskie leksemy żrebij i wróżę (Brukner, 1985:301). W niemieckim Loos znajdujemy starożytny indoeuropejski korzeń *hlot - z głównym znaczeniem «rzucać» (stąd współczesne włoskie lotto - «lotto» i lotteria «loteria»). Tak, więc, pierwotne znaczenie tego imienia, zgodnie z etymologią to «żrebij», za pomocą którego ustalony jest porządek czy kolejność, w odniesieniu do osoby - jest to przebieg wydarzeń życiowych (bieg życia), zbieg okoliczności: To niezupetnie tak. To pierwszy reportaż, który opisuje marny los klasy robotniczej w Polsce (M. Nurowska).

1.Drugie znaczenie leksemu los («przeznaczenie, fatum») nawiązuje do wierzeń ludowych, do tradycyjnego przedstawienia losu jako pewnej nadprzyrodzonej siły, która ma wpływ na życie człowieka: $O$ tym, kto z nich stał się więźniem, decydował los (A. Pawełczyńska). Od czasów starożytnych uosobieniem losu w Ukraińcach i Polakach była 
Dola, żeńskie bóstwo, przędzone nici losu człowieka, określające jego dalsze życie (4). Nazwa danego bóstwa pochodzi od czasownika «dzielić», stąd Dola jest tym, co obdarza. Zarówno w języku ukraińskim, jak i polskim nadal funkcjonują odpowiednio leksemy «los» i «dola», pierwotnie oznaczające właśnie wydzieloną część. We współczesnym języku ukraińskim pierwotnym znaczeniem słowa «los» jest znaczenie - «część czegoś» (Slovnyk ukrayinskoyi movy, 1970-1980:169), sięgające początkowego «dzielić», a jedynie wtórne znaczenie tej nazwy - «udział, los». We współczesnym języku polskim podział znaczeń jest inny: dola - 1. «los przypadający komuś w udziale»; 2. pot. «część przypadająca na kogoś z podziału zdobyczy, zarobionych wspólnie pieniędzy itp».(2). Rozwój znaczenia «los»u leksemów «los» i «dola» przebiegał najwyraźniej wzdłuż linii sprecyzowania: «zaznaczona część» $\rightarrow$ «rozwijana część, los» $\rightarrow$ «przeznaczenie». Według danych «Elektronicznego słownika języka polskiego XVII i XVIII wieków», najwcześniejsze wspomnienia słowa «dola»w znaczeniu «los» w pisemnych tekstach datują się 1656 r. (6). «Dola» w polskiej kulturze - dobry udział, szczęście, szczęśliwy los; dola (w tej i w upersonifikowanej postaci) jest przeciwstawiona niedoli, niedola - «gorzki los, udział»: Bo z nowym panowaniem niedola chłopa jeszcze się pogorszy (W. Reymont, NKJP).

\section{Wyniki badania}

O losie, dole jako pewnym przeznaczeniu, czymś niezmiennym mówią następujące wyrażenia: Co ma być, to będzie; Nie wiemy, jaki kotek dola na nas struże; Doli swojej koniem nie objedziesz. Człowiek w tym przypadku jest zabawką w rękach losu, komuś daje wiele, komuś - nic: Los igra z człowiekiem (Przysłowie); Do jednych los się uśmiecha, z innych się śmieje (T. Maryniak); Los jednemu da aż nadto, a drugiemu wydrze oczy (Przysłowie). O człowieku, o nieszczęśliwym losie mówi się jako o ofierze: Człowiek nie zawsze jest kowalem własnego losu, czasem jego ofiara (B. Bujak).

Istnieje jednak wręcz przeciwny pogląd na los człowieka w polskiej kulturze, jak głosi przysłowie: Każdy jest kowalem swego losu, tzn. każdy człowiek sam tworzy swój los, może aktywnie na niego wpływać, zmieniając swoje życie. A jeśli pierwszy punkt widzenia na los sięga od najstarszych wierzeń (nie tylko słowiańskich), będąc we współczesnej kulturze wyrazem mitologicznego fatalizmu, to drugi - do sentencji rzymskiego poety z epoki IV w.p.n.e. Appia Klaudiusza Cecka (Faber est suae quisque fortunae), twierdząc aktywną, twórczą rolę człowieka we własnym losie.

Znaczenie danej koncepcji w kulturze można ocenić na podstawie liczby słówsynonimów reprezentujących tę koncepcję w języku. W języku polskim synonimami rzeczownika «los», oprócz już wspomnianego leksemu «dola», są słowa: przeznaczenie, życie, stylistycznie oznaczona opatrzność, fatum, fortuna i inne (Elektroniczny słownik języka polskiego XVII i XVIII wieku: środek elektroniczny, 2015:103). Jednym z wtórnych znaczeń leksemu przeznaczenie jest «nieunikniona przyszłość, nieuchronna konieczność nadejścia, stania się czegoś» (3), główną semą tego znaczenia jest «nieuchronność»: Przeznaczenie stoi za ludźmi, welonem tajemnicy zasłonięte, $i$ w dłoni trzyma kołczan z tysiacem zdarzeń (E. Orzeszkowa). Przeznaczenie - dosłownie «to, co jest przypisane», zdefinionowane $\mathrm{z}$ góry. Los, przeznaczenie, jak wskazano powyżej, są nieuchronne, obowiązkowe, nieuniknione, mają pewną siłę nad człowiekiem. Ten ostatni, z kolei, albo chętnie wierzy w cel, albo go odrzuca: Chociaż nikomu nie trzeba tlumaczyć, że Święty Mikołaj nie istnieje, Wróżka Zębuszka nie kolekcjonuje mleczaków, a katecheta nie ma bladego pojęcia co dzieje się po śmierci, to zastraszająco duża liczba osób wciąż wierzy w przeznaczenie (Blog Internetowy «Mr K. passion», 23.06.14); Ja nie wierze w przeznaczenie, bo to by oznaczało, że nie mam wptywu na swoje życie i jestem tak naprawde kukiełka $w$ rękach Losu. Wolę żyć ze świadomościa, że to ja decyduję co i jak (Forum Internetowe «Netkobiety.pl», 31.01.11).

Współczesny człowiek wydawałoby się daleko od świadomości mitologicznej, jest jednak bardziej skłonny wierzyć w cel, taki wniosek został wyciągnięty na podstawie analizy komentarzy użytkowników jednego z polskich forów internetowych «Zapytaj» (26.03.11). $\mathrm{Na}$ pytanie: «Czy wierzysz w przeznaczenie?» - większość $(61,1 \%)$ odpowiedziała 
pozytywnie, 16,6 \% uczestników badania utrudniali się odpowiedzieć jednoznacznie, tyle samo odpowiedziało kategorycznie «nie» a 5,7 \% użytkowników wskazało, że więcej wierzą w przypadek. Taki podział odpowiedzi nosicieli języka polskiego świadczy o głębokim zakorzenieniu tradycyjnych (starożytnych) poglądów na los.

Uważa się, że los jako najwyższy początek rozporządzenia określa życie człowieka: Los tak chciat, on wciąz kieruje moim życiem (Forum Internetowe). Z kolei życie człowieka może być częściowo utożsamiane $\mathrm{z}$ losem, ponieważ los w znaczeniu pierwotnym to «bieg zdarzeń» («przebieg wydarzeń»), czyli pewien proces, a życie $w$ jednym $z$ drugorzędnych znaczeń - to proces istnienia (்̇cie - 2. «proces bytowania, egzystowania przebiegający w jakiś sposób lub w jakichś warunkach»(9). Takie utożsamianie wyraża się w możliwości używania leksemów los i życie jako synonimicznych w obrębie jednej konstrukcji składniowej: Głęboko w sercu wiedziałam, że nie jestem panem swego życia, że ktoś czuwa nad moim losem (Forum Internetowe). Losy człowieka, jego życie mogą być określane przez osoby lub wydarzenia: Z perspektiwy czasu odkrywam, jak wielki wplyw na moje życie wywart ten czlowiek (T. Nadrowski); Potem byty wydarzenia mniej lub bardziej ważne, ale wszystkie miały swój sens $i$ cel $i$ wywarly ogromny wpływ na moje życie (A. Młynarska). Ponadto samo życie, podobnie jak przeznaczenie, może być postrzegane jako najwyższy początek, stojący nad człowiekiem, co wyraża się metaforami typu «życie śmieje się z...», «życie kieruje...»: Pozostałe dwa mówią: «dzikie życie wchłania nas» $i$ «dzikie życie śmieje się z nas» (NKJP); Czy wy też czasami czujecie, że życie kieruje wami, a nie wy nim? (Forum Internetowe). Życie, a raczej sposób życia, z kolei może decydować o dalszym losie człowieka (Z biegiem czasu zaczęłam cierpieć z tego powodu, ponieważ miałam wyrzuty sumienia, że postępuję źle, a nie mogłam nic zmienić, byłam już zbyt słaba, złe życie przejęło kierowanie moim losem. Forum Internetowe), w tym przypadku los nie jest postrzegany jako coś nadane z góry, ale jako przyszłość (przyszłe życie), całkowicie zależne od samej osoby lub jakichkolwiek okoliczności.

Cechą odróżniającą życie od losu, może być: życie można zmienić, przepisać, zacząć od nowa (Gdy jej mąż skończyt 43 lata, dla niej zaczęlo się nowe życie. Katorga. E. Wolnik, NKJP; Nasze życie zmienito się, gdy Ojciec zacząt pracować $w$ dyplomacji. M. Iwaszkiewicz, NKJP), los nie może się zmienić. O tym, że los w świadomości nosicieli języka polskiego jako coś przeznaczone $z$ góry określa się poprzez znak trwałości, świadczą i antonimy słowa los - zbieg okoliczności, splot wydarzeń, przypadek, traf, ustalone słownikami (Elektroniczny słownik języka polskiego XVII i XVIII wieku: środek elektroniczny, 2015:103). Istotne, $\mathrm{z}$ punktu widzenia ludzkiej świadomości, różnice $\mathrm{w}$ zjawiskach, przedmiotach, zjawiskach realnej rzeczywistości znajdują odzwierciedlenie w języku jako przeciwieństwie (zjawisko antonimii), stąd los w polskiej kulturze jest czymś niezmiennym, przeciwstawionym przypadkowi, zbiegowi okoliczności, tak mówi logika języka. Z drugiej strony, stosunek do przypadku, zbiegu okoliczności u nosicieli niejednoznaczny, co definiuje się jako przypadek, może być regularnością, znakiem losu, przeznaczeniem : Nie ma zbiegów okoliczności ... to tylko sposób, w jaki przeznaczenie zwraca nasza uwage (E. Siarkiewicz); Uklad przypadków to właśnie przeznaczenie (W. Myśliwski); Nieraz zastanawiam się, jaka role $\boldsymbol{w}$ życiu pelni przypadek. Właściwie go nie ma, każde zdarzenie czemuś stuży, po coś się dzieje i dlatego nie wolno go lekceważyć. Jest dotknięciem losu (M. Zawadzka).

Leksema fatum w języku polskim ma dwa znaczenia: 1. «siła wyznaczająca bieg wydarzeń»; 2. «zły los» (2). W pierwszym znaczeniu jest to rodzaj siły, który predestynuje bieg wydarzeń: Jest on przykładem człowieka nad, którym nie ciąży żadne fatum, a jego decyzje sa podejmowane dobrowolnie, zgodnie z jego wtasna idea (Forum Internetowe). To znaczenie z punktu widzenia etymologii jest bezpośrednio związane z łacińskim «fari» (stąd fatum - pierwotne «słowo, powiedzenie bogów»), oznaczające «mówić, przewidywać» (9). Fatum - to, co zostało powiedziane, przepowiedziane z góry. Drugie znaczenie polskiej nazwy fatum zgodne ze znaczeniem ukraińskiego rzeczownika fatum - «nieszczęśliwy los» (Slovnyk ukrayinskoyi movy, 1970-1980:672), por.: Fatum jak cień, tuż za mna jest. (Forum Internetowe); I dzieciom fatuma miejsca $w$ świecie nie ma / I ja raz byłam szczéśliwa, taka 
szczęśliwa... To fatum... (Lesia Ukrainka). W języku łacińskim słowo fatum oznacza «Rock, los, przeznaczenie» było wtórne, powstałe na podstawie metonimicznego przeniesienia pierwotnego znaczenia: rock, los $\leftarrow$ przepowiedziane, nieuniknione. Obecność konotatywnej semy «nieszczęśliwa» pozwala rozróżnić polskie los i fatum, ukraińskie dola i rock, w danym przypadku leksemy los, dola są hiperonimami w stosunku do fatum i rock odpowiednio; w końcu los w całości można zdefiniować jako szczęśliwy, dobry: Miał sto innych dla nas szans / Lecz dat największą, ufat nam / Łaskawy los, szczęśliwy los (J. Kukulski); Jak widać, dola rzuciła mnie aż na Krym. (Michał Kocubiński).

Istnieje w języku polskim i trwałe wyrażenie, które można uznać za synonim słowa fatum w drugim znaczeniu - ślepy los - «bezlitosny, bezwzględny, surowy przypadek» (10), ślepym losem Polacy nazywają bezwzględny, okrutny, surowy przypadek: Catym światem przypadek i los rzadzi ślepy (F. Zabłocki).

Latynizm fortuna w swoim pierwotnym znaczeniu - «los, zwłaszcza dobry» (2), w przeciwieństwie do wtórnego znaczenia słowa fatum, oznacza szczęśliwy los: Nie tyle talent, co ślepy przypadek i fortuna rządza naszą kariera (J. Abramow - Newerly, NKJP). Pozytywna semantyka tego słowa nawiązuje do uosobionej reprezentacji fortuny w mitologii rzymskiej. Fortuna u Rzymian była boginią płodności, urodzaju, a więc szczęścia, powodzenia. Dla porównania: w języku ukraińskim podstawowym znaczeniem słowa «fortuna» jest: 1. «los, przypadkowe szczęście» (Szyjewski, 2003:845), obecność wyróżniającej semy «przypadek» sugeruje, że w świadomości ukraińskojęzycznych fortuna wydaje się raczej nie tylko jako udany, szczęśliwy los, a coś nietrwałe, szczęśliwy przypadek, innymi słowy: Historia Instytutu zapomniała się, a kapryśna fortuna niezmiennie przyczyniła się do szczęścia... (Lubomir Dmyterko). W języku polskim, a także w ukraińskim jest zrównoważone wyrażenie «koło fortuny»: Koto fortuny wcią̇ nie dla mnie toczy się. (Forum Internetowe); Kisielewski nie doczekat się już tej minuty, kiedy koło fortuny musiało się odwrócić przydatnie dla niego. (Iwan Franko, VI, 1951, 237); I oto teraz... tak powiedzieć... koło fortuny zarzuciło mnie do zimnej Syberii (W. Szyszkow). W języku polskim ten frazeologizm oznacza nieprzewidywalność, zmienność ludzkiego losu, w języku ukraińskim - zmienne, nietrwałe szczęście. Te stabilne wyrażenia nawiązują do tradycji przedstawiania starożytnej rzymskiej bogini Fortuny, która siedziała w koronie na środku dysku i stale obracała go (12). Istnieje w języku polskim przysłowie «Fortuna kołem sie toczy» (Fortuna toczy się kotem, kto dziś górą, jutro dołem), wyrażające znaczenie zmienności, gwałtownej zmiany losu. Jednak obraz koła fortuny może być interpretowany i inaczej: koło stale obraca się w kręgu, zatem wszystko się zmienia, ale przychodzi (powraca) z czasem do punktu wyjścia, czyli to, co jest jego przeznaczeniem, nieuchronnie, i jak nie zmieniałoby się życie człowieka, wróci do tego, co przesądzono pewnymi siłami wyższymi.

Istnieją w języku polskim i frazeologizmy, określające wybrańca losu, człowieka szczęśliwego, pomyślnego w życiu: ulubieniec fortuny, wybraniec fortuny (Ja myślę, że Komorowski jest po prostu ulubieńcem fortuny. Forum Internetowe). W sytuacji powodzenia, szczęścia Polacy używają innego trwałego wyrazu - uśmiech fortuny, fortuna (los) uśmiecha się do kogokolwiek: Niezbyt często fortuna uśmiecha się do pana prezesa (Forum Internetowe). Przeciwnie, w sytuacji pecha, niepowodzenia mówią o kaprysach fortuny (kaprys fortuny): Wedtug ich przekonań, nie należy za bardzo się smucić ani też cieszyć, ponieważ fortuna jest zmienna i lepiej być przygotowanym na jej kaprysy (Forum Internetowe).

Człowiek inaczej odnosi się do losu: od całkowitej uległości (Nasze przeznaczenie ciagle nad nami ciąży i nie można przed nim uciec. Walka z nim nie ma większego sensu. Forum Internetowe) do buntownictwa i konfrontacji (Walka z losem ma sens nawet wtedy, kiedy z góry skazana jest na porażkę. Rebelya.pl, 22.10.11). Jednak uważa się, że konfrontacja z losem jest bezcelowa, przyniesie tylko nieszczęście: Wydaje mi się, że rodzac się, dostajemy tzw. «przeznaczenie», ale to od nas zależy, co z nim zrobimy, czy pójdziemy razem z nim, czy przeciwstawimy się mu. Sądzę, ̇e ludzie przeciwstawiajacy sie przeznaczeniu nie będa zbyt szczęśliwi (Forum Internetowe). W związku z tym osoba jest gotowa uznać nie tylko rządy losu, ale także jego racjonalność: wszystko, co daje konkretnej 
osobie jest poprawne. Nie bez powodu o człowieku, który niepotrzebnie ryzykuje, Polacy mówią, że on kusi/prowokuje los i czasami tego nie warto robić: Na wszelki wypadek nie pozwolitam się odprowadzić - lepiej nie kusić losu (Słownik języka polskiego).

Stosunek losu do człowieka jest odciśnięty w szeregu polskich frazeologizmów: los płata komuś figle (człowiek nigdy nie wie, co jest przeznaczone dla niego losem), los kogos prześladuje (tak mówią o serii pechów, niepowodzeń, nieszczęśliwych wydarzeń w życiu kogoś), los spłatat komuś figla, los komuś sprzyja (11). Z jednej strony los może człowieka prześladować, grać z nim żart (i nie zawsze dobry): Los prześladuje mnie nie na żarty! (B. Prus); Lecz jak to bywa - los figle ptata, maleńka kropla nie naprawi świata. (Forum Internetowe). Z drugiej - sprzyjać, pomagać w czymś: Jak do tej pory to los mi sprzyjal w poszukiwaniu i znajdowaniu wiedzy, która chciatem posiadać (Forum Internetowe). Los można określić za pomocą trwałych lub luźnych kombinacji, jako okropny, niesprawiedliwy lub, przeciwnie, pomocny, laskawy: Okrutny los sprawil, że wraz z mężem staliśmy się dyrygentami w tragicznych okolicznościach (A. Różycka), Niesprawiedliwy los, zabiera nam ludzi / Podłe uczucie nieszczęścia w nas budzi. (kobieta.pl, 23.09.2005); W sobotę los byt dla naszej drużyny narodowej dość taskawy (Se.pl), Laskawy los to prawo dat / Znaleźć się, zrozumieć się (Piosenka). Frazeologizmy z podobną semantyką są reprezentowane przez dwie grupy w języku polskim : 1. «przymiotnik + rzeczownik los» (taskawy los, okrutny los); 2. «rzeczownik z semą konotacyjną + rzeczownik los» (niesprawiedliwość losu, okrucieństwo losu, złośliwość losu).

Jednym z narzędzi konceptualizacji wiedzy o świecie jest metafora. Konceptualna metafora jest mechanizmem, pozwalającym na strukturę odrębnej sfery w kategoriach drugiej, tworząc w ten sposób odmienną (nową) wizję tego zakresu. Wśród metaforycznych reprezentacji koncepcji «los» najbardziej przedstawioną jest antropomorficzna metafora, co można wyttumaczyć z jednej strony obecną zasadą antropocentryzmu w języku i poznaniu świata przez człowieka jako całość, z drugiej strony, ponieważ los postrzegany jako początek aktywny, czasami rozsądny, jego reprezentacja na obrazie i poprzez oznaki człowieka jest całkiem uzasadniona. Tak więc los, podobnie jak człowiek jest obdarzony intelektualnymi zdolnościami, może osądzać/rozumować, decydować o wszystkim: Zreszta skoro los sądzil, że może jej dyktować, w kim ma się zakochać, czekała go niespodzianka (M. Steifvater); I tak zaczętam, choć później los decydowal inaczej, co i rusz oddalajac mnie od mojej pasji, moich marzeń (Forum Internetowe). Jednak, pomimo przypisywanego znaku «racjonalności», uważa się, że los rzeczywiście wyznacza coś, decyduje na ślepo: $A$ «los» dziala na oślep (Forum Gazety.pl); Los obdarza nas sytuacjami, zdarzeniami bez względu na to, czy mamy pieniadze, czy ich nie mamy (Forum Internetowe), stąd niezadowolenie człowieka z jego losu, z tym, co z nim odbywa się w życiu (przecież często jego oczekiwania nie są spełnione).

Los ma umiejętności, charakterystyczne dla człowieka, w szczególności, w stanie pisać, rysować: Czasem żahuje, że los nie pisze życia ołówkiem (Forum Internetowe), Pamiętaj los rysuje Ci szkic, ale to Ty dobierasz kolory swojego życia (Forum Internetowe). Produktem tej «twórczej» działalności losu jest życie człowieka, przy czym podane przykłady odzwierciedlają dwojaki pogląd człowieka na to, co zostało stworzone przez los: pierwszy przykład (czasami żałuję, że los nie pisze życia ołówkiem) pokazuje niemożliwość zmiany czegokolwiek w swoim życiu (to, co jest przygotowane losem, jest nieuniknione), drugi - ilustracja aktywnej roli człowieka w jego własnym życiu (los tworzy tylko szkic, kolory dla własnego życia podbiera sam człowiek).

Odznaczają się w losie i socjalne oznaki, nazywane scenarzystą życia kogoś lub jakiegokolwiek wydarzenia: Los pisze nam przeróżne scenariusze (Forum Internetowe); Tak to los pisze dziwne scenariusze - komentuje juz po wyborach Teresa Mazurek (A. Bielawska). Los nie jest po prostu pomyślany jako twórca ogólnego scenariusza, on decyduje o indywidualnej roli, którą człowiek będzie odgrywał w teatrze pod nazwą «życie» : Los każdemu wyznacza rolę, która każdy znosi tylko dlatego, że widzi się w niej z jak najlepszej strony (W. Grzeszczyk); Kocha kwiaty, wieś i teatr. Los sprawil, że gra role gawędziarki (Dziennik Polski, 20.07.2013). W przenośni los jest przedstawiany jako krupier rozdający 
karty, którymi osoba będzie grać w życiu (przy czym ponownie podkreśla się bierność człowieka, niemożliwość zmiany czegokolwiek, porozdawane «karty» nie można zmienić ani ponownie wydać): Los to taki krupier, który rozdaje karty. Mnie niestety dat więcej serca niż rozuти... (Forum Internetowe); Los rozdaje karty, nie ma szans na nowa talię (Piosenka).

Los gra z człowiekiem, bawi się nad nim, często oszukuje: Wiesz - mówi - byłam pewna, że los gra ze mna znaczonymi kartami (A. Nowakowska); Człowiek-lalka, którym los bawi się, zwodzac go i oszukując (C. Milosz). Jest w stanie aktywnie ingerować w ludzkie plany, udaremnić to, co zamierzał: Niestety, los pokrzyżowal te plany (Kurier Lubielski, 15.01.2014); Zaplanowali idealne wesele, ale los pokrzyżowal im plany (Forum Internetowe). Jednak los może być dość miłosierny, może obdarzyć/dać coś, przedstawić niespodziewane lub długo oczekiwane prezenty: Uroda to niestety dar losu, nierówno rozdzielony między ludzików (Gazeta.pl, 24.01.2002); No to byt wymarzony prezent od losu. Czymś sobie na to zastużyłam (M. Kożuchowska); Dostajemy od losu dar, czyli możliwość tworzenia, kreowania rzeczywistości (Forum Internetowe). Uważa się, że los przejawia troskę o człowieku, ostrzegając go przed nierozważnymi decyzjami, krokami przez jakiekolwiek wydarzenia, zjawiska: Dlatego warto uważnie podchodzić do dawanym nam przez los ostrzeżeń $i$ dobrze wykorzystać kolejna szansę (Forum Internetowe).

Los jest zdolny do konkretnych działań fizycznych: Przechadzal się los po tace, wszystkim napotkanym rozdawat szczęście, mnie pominat! (kobieta.pl, 11.03.2008); Z czasem czlowiek mówi sobie „e tam co ma być to będzie” $i$ spokojnie czeka na to co przyniesie los $i$ nawet gdy niklym plomieniem zablyśnie w glowie myśl by jakoś pomóc losowi to zaraz płomyk dusi się w oparach ,przeciez nigdy nic mi nie wychodzito, jeśli los tak chce to tak będzie nie oszukam przeznaczenia" (Forum Internetowe). Leksema «los» i jej synonimy są najczęściej łączone z czasownikami alienacji czy przekazywania obiektu (Czy los ma swoich wybrańców? Jednym daje dużo, a innym skapi najprostszych rzeczy. Forum Internetowe; Los odbiera, los daje. Futbolowo.pl, 13.09.2014), czasownikami jednokierunkowymi (Wielu z nich mieszka w Polsce, kogoś los rzucit do Anglii, Stanów Zjednoczonych, do Niemiec. Wschodnia Gazeta, 19.08.2015; Przeznaczenie urochamia się nie tylko wtedy, by zrobic nam krzywdę-ale także wtedy, by pchnaćc nas na wlaściwa ścieżkę życia. Blog Internetowy; Mąrego los prowadzi, glupiego - popycha. W. Grzeszczyk; Przypadek to tylko bat, którym przeznaczenie pogania to, co nieuchronne, do przodu. J. Głowacki; Jest natomiast los, który prowadzi nas przez życie dostarczając kolejnych lekcji, które nam sq potrzebne. Forum Internetowe).

Podobnie jak człowiek, los może chcieć czegokolwiek, doświadczać pewnych uczuć (lubić, nienawidzić, żałować): Dziura w niebie, los tak chcial... (Forum Internetowe); Los kocha tych, co ufaja mu... (Forum Internetowe); Dość. Żle. Los mnie nienawidzi / Czemu? pytam się. / Czemu znów ten los mnie tak rani... / Czemu uczepit się mojej rodziny... (Forum Internetowe).

Los jak wyższy dysponent występuje jako łączący początek (łączy ścieżki życia ludzi, wydarzenia zachodzące po drodze), a następnie jako początek dzielący, rozłączający: Los taczy ludzi na pewno nie z przypadku (Forum Internetowe); Los czasem oddziela sobie bliskich ludzi, żeby uświadomić im, ile dla siebie znacza (Forum Internetowe). Dwoistość losu przejawia się w tym, że może zarówno podtrzymywać ludzi, pomagać im, choć w swoisty sposób (Los wspiera nas ciosami i nieszczęściami naszych bliźnich. A. Kamieńska; Silnym los pomaga. Przysłowie), a więc przeszkadzać człowiekowi w czymś, grozić mu, uderzyć (Czy mi przeznaczenie przeszkadza w uczeniu się? Nie wiem... Forum Internetowe; Chuchaliśmy na nia i dmuchaliśmy, a potem dostaliśmy cios od losu-mówi dziś Arkadiusz Kuczyński. Tygodnik Ostrołęcki, 30.12.2014).

\section{Wnioski i perspektywy}

Podsumujmy: bliskie zainteresowanie człowieka zjawiskiem «los» jest odzwierciedlone przez dużą liczbę jednostek językowych określających nazwany koncept $\mathrm{w}$ języku polskim (15 synonimów, 40 jednostek frazeologicznych ze składnikami «los / przeznaczenie / fortuna»). W polskim językoznawstwie «los» - jest zarówno najwyższym 
początkiem, jak i przebiegiem wydarzeń i życia (w tym przyszłością, jej kluczowymi wydarzeniami). Los jest uważany za początek sprzeczny, ambiwalentny, co wyraża się i w charakterze jego przejawu (pomaga - przeszkadza, lubi - nienawidzi, taczy - rozłacza, daje odbiera itp.), i jego oceny przez człowieka (mitosierny, dobry - okropny, zły). Jest dwojaka i przyroda stosunku do losu u przedstawicieli kultury polskiej: od całkowitego jej zaprzeczania (Nie istnieje coś takiego jak predeterminowany los, przeznaczenie. Swoja przyszłość budujemy każdego dnia) do czasu uznania jej rządów (Nie można zmienić tego co z góry ustalone), od całkowitego poddania się podporządkowaniu losowi (To los ma nad nami przewagę, a nie odwrotnie) do walki z nim (Wierzyć i walczyć - a nie przeżyć, myśleć $i$ pogodzić się z losem).

\section{LISTA LITERATURY}

Кононенко, 2004 - Кононенко В. I. Концепти українського дискурсу. К. ІваноФранківськ: «Плай», 2004. 248 с.

Słownik, 2014 - Stownik języka polskiego: środek elektroniczny. Tryb dostępu: http://sjp.pwn.pl/slownik (data zwrócenia 20.06.2014).

Brukner, 1985 - Brukner A. Słownik etymologiczny języka polskiego. Warszawa: Wiedza Powszechna, 1985. $806 \mathrm{~s}$.

Szyjewski, 2003 - Szyjewski A. Ciało i dusza w wierzeniach dawnych Słowian. Kraków: Wydawnictwo WAM, 2003. $268 \mathrm{~s}$.

Словник, 1980 - Словник украӥнської мови: в 11 тт. / АН УРСР. Інститут мовознавства; за ред. І.К. Білодіда. Київ: Наук. думка, 1970 - 1980.

Elektroniczny słownik, 2015 - Elektroniczny stownik języka polskiego XVII i XVIII wieku: środek elektroniczny. Tryb dostępu: http://sxvii.pl/ (data zwrócenia 01.05.2015).

Słownik, 2002 - Słownik synonimów i antonimów / red. M. Pawlus. Kraków: Drukarnia Narodowa, 2002. $484 \mathrm{~s}$.

Wielki słownik, 2015 - Wielki słownik języka polskiego: środek elektroniczny. Tryb dostępu: http://www.wsjp.pl/ (data zwrócenia 01.05.2015).

Słownik, 2015 - Słownik frazeologiczny języka polskiego: środek elektroniczny. Tryb dostępu: http://www.edupedia.pl/ (data zwrócenia 01.05.2015).

Гуревич, 1984 - Гуревич А. Я. Категории средневековой культуры. М.: Искусство, 1984. $350 \mathrm{c}$.

Korpus, 2014 - Korpus języka polskiego: środek elektroniczny. Tryb dostępu: http://korpus.pwn.pl/ (data zwrócenia 20.06.2014).

\section{REFERENCES}

Kononenko, 2004 - Kononenko V.I. Koncepty ukrayinskogo dyskursu [Concepts of Ukrainian discourse]. K. Ivano Frankivsk: «Play», 2004. 248 p.

The dictionary, 2014 - The dictionary of the Polish language: electronic resource. Access mode: http://sjp.pwn.pl/slownik (date of request 20.06.2014).

Brukner, 1985 - Brukner A. Etymological dictionary of the Polish language. Warsaw: Common Knowledge, 1985. $806 \mathrm{p}$.

Shyjevski, 2003 - Shyjevski A. Body and soul in the beliefs of the old Slavs. Krakow: Publishing WAM, 2003. $268 \mathrm{p}$.

Slovnyk, 1980 - Slovnyk ukrayinskoyi movy v 11 tomax [The dictionary of the Ukrainian language: 11 book] - K.: Scientific thought, $1970-1980$.

Electronic dictionary, 2015 - Electronic dictionary of the Polish language XVII and XVIII century: electronic resource. Access mode: http://sxvii.pl/ (date of request 
01.05.2015).

Dictionary, 2002 - Dictionary of synonyms and antonyms / ed. M. Pawlus. Krakow: National Printing Office, 2002. 484 p.

Large dictionary, 2015 - Large dictionary of the Polish language: electronic resource. Access mode: http://www.wsjp.pl/ ( date of request 01.05.2015).

Phraseological dictionary, 2015 - Phraseological dictionary of the Polish language: electronic resource. Access mode: http://www.edupedia.pl/ (date of request 01.05.2015).

Gurevich, 1984 - Gurevich A. Ya. Kategorii srednevekovoj kultury [Categories of medieval culture]. M.: Art, 1984. 350 p.

Polish, 2014 - Polish language Corps: electronic resource. Access mode: http://korpus.pwn.pl/ (date of request 20.06.2014).

Received: 17 June, 2020 
